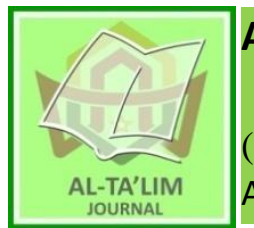

AL-TA'LIM JOURNAL, 26 (1), 2019 (56-64)

(Print ISSN 1410-7546 Online ISSN 2355-7893)

Available online at http://journal.tarbiyahiainib.ac.id/index.php/attalim

\title{
The Problematics of Islamic Religious Education Teacher In Using of Instructional Media at SD Negeri 06 Pancung Soal Pesisir Selatan
}

Received: $28^{\text {th }}$ October 2018; Revised: $22^{\text {th }}$ January 2019; Accepted: $28^{\text {th }}$ February 2019

Permalink/DOI: http://dx.doi.org/10.15548/jt.v26i1.526

\section{Alfurqan *) \\ Universitas Negeri Padang, Indonesia \\ E-mail: alfurqan@fis.unp.ac.id}

\section{Muhammad Tamrin}

Universitas Bung Hatta Padang, Indonesia

E-mail: $\underline{\text { m.tamrin@bunghatta.ac.id }}$

\section{Zulvia Trinova}

Universitas Islam Negeri Imam Bonjol Padang, Indonesia

E-mail: zulvia.trinova12@gmail.com

\section{Zuhdiyah}

Universitas Islam Negeri Raden Fatah Palembang, Indonesia.

E-Mail: zuhdiyah_uin@radenfatah.ac.id

\section{*) Corresponding Author}

\begin{abstract}
The purpose of this study is to describe the condition of PAI teachers in teaching related to the use of instructional media. This study uses a qualitative approach. The instrument of this research is the researcher himself. Key informants are PAI teachers, while supporting informants are principals, teachers and students as well as other informants who are obtained by using snow-ball sampling. The findingsof the study obtained an overview of the conditions of theimplementation of the process of religious learning conducted by the teacher. In this case therelationship with variations in using instructional media. It was found in this study that in generalthe teaching teacher was accustomed to traditional ways and could not use the media. Besidesthat, the instructional media available in schools cannot be used for various reasons. And eventeachers have been satisfied with the teaching conditions that have been carried out for years, so they are not interested in using the right instructional media in accordance with the learningmaterial provided.
\end{abstract}

Keywords: Discourse types recognition, names of discourse types, cultural specifity

How to cite: Alfurqan, A., Tamrin, M., Trinova, Z., \& Zuhdiyah, Z. (2019). The problematics of Islamic religious education teacher in using of instructional media at SD Negeri 06 Pancung Soal Pesisir Selatan. Al-Ta Lim Journal, 26(1). doi:http://dx.doi.org/10.15548/jt.v26i1.526

\section{INTRODUCTION}

Learning is a process of interaction that occurs between the teacher or educator with a group of students or students. In the same condition, the process of interaction in learning also occurs between one student and another student (Jung, Choi, Lim, \& Leem, 2002; Levin, Pieraccini, \& Eckert, 2000; Marrocco, 2009; R. Sun, Slusarz, \& Terry, 2005). The interaction process is intentionally created or designed by the teacher to convey all information both related to the subject matter and other information that must be conveyed to all students (Bhatt, 2001). The interaction process can also be in the form of penalties or gifts like awards or praise to students. Likewise the Islamic Religious Education (PAI) teacher in delivering religious material.

Conditions like this will always continue for a predetermined period of time, until all religious learning plans are carried out until the evaluation stage at the end of the semester. During this period, the process of 
interaction between one element with another element in learning is absolute.

There are at least approximately five months of the effective teaching learning activity in one semester. The teaching and learning activity is carried out every day, facing the same students, the same place and the same conditions (Bates \& Poole, 2003; Laurillard, 2013). In this routine, as if teachers are not able to create a variety of learning in every meeting, then certainly it will be boring learning activities for teachers especially for students. This is where the role of teachers is required to be able to create or change the atmosphere in such a way that all students always feel fun and enjoyable in their study. Things like this can be created by teachers utilizing teaching techniques with the help of various media learning and applying appropriate learning methods (Blase \& Blase, 2000; Egan, 2005; Hackathorn, Solomon, Blankmeyer, Tennial, \& Garczynski, 2011).

In carrying out their daily duties, a PAI teacher should always require and provide learning tools. The tools of which are in the form of facilities and infrastructure associated with the substance or subject matter, such as textbooks, teaching aids and others. In addition, teacher should also provide suitable instructional media. All of them must be possessed by the teacher in order to deliver learning material easily. In addition, by using the medium of learning, students can easily understand and absorb the learning materials from the teachers

According to Iffah (2018); Suryani (2009) media is all forms of medium used by the disseminator of ideas, so that idea or ideas can be delivered to the receiver. When we relate the media with learning, then we have ainstructional media. The understandings that can be gained from these two words are the media is a medium between teachers and students. In other words, the media is a tool that serves as a mediator or liaison between the donors to the recipient of information in the learning process. In this case the information providers are teachers, while the recipients are the students. The function of instructional media is to help teachers deliver the learning materials easily. On the other side, the subject matter that is presented by teachers by using instructional media will be more easily digested by the students or learners. Thus the teacher will be easier in carrying out their duties on the learning objectives that have been defined will be more easily delivered within a specified time (Church, 2008; Taiwo, 2009).

It cannot be denied, in fact, that in teaching activities, a teacher cannot be separated from instructional media, including PAI teachers. Because without the presence of the media, logically the information provided by the teacher will not arrive well to students. Because there is no media to transfered or convey the information to the recipient, the student. Like what researchers have observed in the ongoing learning process in elementary school. At that time the researcher disguised himself as a printing product salesman, so the presence of researchers at the location was not suspected as an observer.

When a young teacher is teaching English subjects. Later it was discovered that the teacher was an honorary staff at the school. Some of the words in English were written on the blackboard, then the teacher while sitting in his chair in front of the class gave instructions to all students to follow what he said. Then the teacher starts reading word by word in English according to what is written on the board. All students speak loudly repeat what teacher reads in front of the class. But the loud voice following the word for word from his teacher was not accompanied by a focus of attention on his teacher. Some say words while playing fingers with their friends behind. There are also students who say the words of their teacher, but do not show any future attention. That was the next, only a few students were seen focusing their attention on the teacher.

Why are there many students who are not paying attention to the teacher's instructions, because learning takes place is not interesting, so that the minds of many students are staring. Although their mouths 
are seen, they continue to say the words the teacher says. But lessons like this will not give a trace of anything in the minds of students (Butt \& Kausar, 2010; Todd, Chaiyasuk, \& Tantisawetrat, 2008).

If the teacher was willing and able to use the instructional media that his school has. It is not difficult to create the atmosphere of learning English so that it will be interesting. The trick is to record the English words with a good voice, if necessary accompanied by a rhythm or certain tones to make it more interesting. Then it is played with the type of recorder in front of the class when English learning takes place. That way the teacher will get some convenience, on one side the teacher no longer struggles to make a sound to say those words. On the other hand the presence of the recoder type in the class will attract students' attention so they learn to be more focused and passionate.

In line with the development of science and technology (science and technology), various forms and models of instructional media have been created with advanced technology. Both the media in the form of audio (hearing), visual (vision) and audio visual are intentionally designed to help smooth the learning process for teachers who are able to run it. To compensate for the development of science and technology in the field of instructional media, PAI teachers are required to have the ability and skills in utilizing the instructional media. Ability in the sense of being able to run these sophisticated instructional media. While the skill in question is the ability of the PAI teacher in choosing and determining instructional media that is suitable with the subject matter to be given, and can also adjust between instructional media with the atmosphere and the learning environment that is ongoing.

In carrying out daily tasks, PAI teachers in elementary schools in PancungSoal sub-district still use natural teaching techniques. Learning carried out has not been accompanied by good planning. The teaching task is only an activity that is done in school. After returning home and leaving school, the teacher no longer cares about what to do next. The problem of teaching at the meeting tomorrow, will be arranged tomorrow after being in the class again.

Meanwhile, other jobs are spent after returning from school until leaving for school the next day. Is it shopping at the market after school, washing, cooking and other homework. It might even be a job like joining a social gathering and busy taking care of business and so on. Conditions like this are sometimes unavoidable for various urgent reasons.

Such is the picture of routines that some teachers follow in carrying out their duties for years. It seems they have not intended to change the techniques and the way they teach. Although in fact they know the kinds of learning methods that can be applied in teaching. They also know a lot of instructional media owned by the institution where they work, which can be used when teaching. Teaching naturally with conditions like this is difficult to change. Although actually the effort to make changes in teaching is often done. Among them by providing various teaching training, upgrading and others, attending seminars, workshops and others. However, after completing the activity, they returned to school and taught in the way they were.

The teaching activity is actually a complex activity. Many things must be prepared by the teacher to plan, so that the atmosphere of learning is created well. Because what is faced by the teacher is humans who have different characteristics and characteristics (Hess, Carlock, Jones, \& Walkup, 2009). On the other hand, the learning conditions will always vary in each of the face-to-face meeting times in accordance with the subject matter to be studied. In addition the atmosphere of the learning environment must also be considered to be considered by the teacher in preparing learning plans.

So many things must be considered by PAI teachers in preparing learning plans. Either it determines the method to be used, as well as maintaining instructional media that 
matches the subject matter to be studied, designs the right learning conditions and adapts the learning process to the ongoing environment. Ideally, a teacher needs a long time to compile and complete learning planning. So actually a teacher does not have time to participate in other activities, because most of the time has already been spent on preparing learning plans. Actually, this is the picture that is actually a teacher in carrying out his duties every day. At home they are preoccupied with preparing learning plans to be applied to learning tomorrow. While the next day the teachers spend time at school throughout the class hours.

\section{Media}

Carrying out the task as a teacher or educator means carrying out tasks related to the delivery of information (material) to the recipient of the information (students). The process of delivering information or material will be very easy for the teacher or educator, as well as for students when using the media. This is in line with the theory put forward by Bretz in Nurseto (2011) says that the media is something that is located in the middle, so an interface that connects all parties that require the occurrence of a relationship, and distinguishes between communication media and tools communication. The statement can be understood that the parties who want to relate between one another will get ease in their work.

Likewise with other work involving communication between several people needed to use the media. According to Falahudin (2014) "the media applies to various activities or businesses, such as the media in delivering messages, magnetic delivery media or heat in the field of engineering." In the process of learning the media also serves to help students easily receive knowledge. Mahnun (2012) suggests that the media are loyal people, materials, tools or events that can create conditions that allow students to receive knowledge, skills and attitudes.

\section{Instructional media}

In some references found the use of terms that are different from instructional media. The term is educational media. Another term found is instructional media. Researchers concluded that this was different terms, but the meaning contained in the use of the term was the same, namely the media used in the learning process (Mayer, 2003; Reiser, 2001; Rodgers \& Withrow-Thorton, 2005; Smaldino, Lowther, Russell, \& Mims, 2008).

The implementation of learning that is supported by the use of appropriate instructional media will provide stimulation that can provide motivation for students. This means that the media function used by the teacher will attract students' willingness to truly follow learning. Muhson (2010) suggests that instructional media are all forms of communication tools that can be used to convey information from sources to students who aim to stimulate them to participate in learning activities. Instructional media also functions to provide reinforcement and motivation. According to Skylar et al. (2005) educational media is anything that can be used to channel messages from the sender to the recipient so as to stimulate students' thoughts, feelings, attention and interests in such a way that the learning process occurs.

On the other hand the task burdened by the teacher in delivering learning material will be greatly helped by using the media. According Almeida, Krueger, Eager, \& Vernon (2001) educational media is a kind of auxiliary or complementary tools used by teachers or educators in order to communicate with students or students. In line with the above opinionthe opinion expressed by Newby, Stepich, Lehman, \& Russell (2000); Rideout (2014); Williams \& Jacobs (2009) education media is a tool, method and technique used in order to make more effective communication and interaction between teachers and students in the process of education and teaching in schools. 
Teachers or educators are always involved in good communication between teachers and students and between students and other students. The communication process will be smooth if it is helped with the use of instructional media (Lässig, 2009). Chen \& Bryer (2012) argues that educational instructional media is a means of communication in the teaching and learning process in the form of hardware and software to achieve instructional processes and results effectively and efficiently, and instructional objectives can be achieved easily. Communication media must be adjusted by the teacher with the material and conditions of learning that are ongoing. Instructional media is everything that delivers or carries information that contains learning material from the teacher to students or learning citizens. This opinion was expressed by Sun $\&$ Cheng (2007). Furthermore according to Wina (2008) "that the teaching media includes hardware and software. Hardware is tools that can deliver messages such as overhead projectors (OHP), radio, television and so on. Whereas software is the content of programs that contain messages such as information contained in transparency or books and other printed materials, stories contained in the film or material presented in the form of charts, graphs, diagrams, etc."

Based on the above explanation can be drawn a conclusion about the instructional media that is everything that can be used by teachers or educators to help facilitate conveying information containing learning material to students. With the help of the instructional media the teacher will be easier to carry out their duties. On the other hand the learning objectives that have been set before are expected to be easily achieved.

\section{METHODS}

This research uses descriptive method with qualitative research. According to Moleong \& Surjaman (1991) that "qualitative methods are a research procedure that produces descriptive data in the form of written and oral data from people and observed behavior."

The use of qualitative methods in this study aims to see the learning process directly carried out by the teacher, whether the teacher is able to vary the learning process using instructional media. Is the teacher able to maximize the use of instructional media owned by the school. In addition to seeing the availability or completeness of instructional media in schools. And see firsthand how far the teacher's ability to use various kinds of instructional media in the school where they are assigned. The qualitative method was chosen in this study with the aim of seeking a study by systematically, factually and accurately describing the facts of a condition when the teacher taught in relation to the use of instructional media in Public Elementary School 06 in PancungSoal District, Pesisir Selatan Regency.

\section{RESULTS AND DISCUSSION}

The location of this research is located in Desa Pasar Sebelah Kecamatan Pancung Soal Kabupaten Pesisir Selatan. This school was founded in 1977. Currently the school already has its own building and is built on land that has been certified as ownership in the name of the local government. In general, public elementary schools in this area already have their own school buildings built by the government. Nevertheless, there are also lands that are represented by community groups for the public interest. Based on the results of observations and interviews that have been carried out some time ago it can be explained as follows:

\section{Obstacles in Using Instructional Media}

There are a number of issues that are a barrier for two PAI teachers in this school to use the instructional media. Among them is a problem that is difficult to overcome that is used to teaching not to use instructional media. Researchers observed that the teachers carried out their assignments in the classroom long 
enough with these conditions. But they feel that there is nothing lacking in carrying out their duties. They are satisfied with what has always been done, and they feel there is no need to change or develop their teaching patterns. From day to day until many years and even decades they have carried out teaching assignments by referring to the textbook, every field of study does not need to be assisted by the media.

It was found that they didn't realize there was a very large role when teaching using the media. Because of their habits, they do not realize that their duties in teaching will be greatly helped by using instructional media. They do not need to make a loud sound for lectures delivering material. They do not need to painstakingly simulate material in the form of practice. Because all that can be done well through the use of instructional media.

In the same condition as the media presence when the teacher is teaching, it will be very helpful for students to arouse their motivation. Because the presence of the media will make variations and attract students' attention so that students always feel entertained. In other words, unwittingly the instructional media function to entertain students when learning. Whatever type of media used can make students entertained when used skillfully. Therefore, the teacher's skill in determining the media that matches the material to be delivered is very necessary.

Furthermore, the problem in using PAI instructional media is the issue of usage permits. School leaders do not always give teachers the opportunity to use or use collected media. There are various reasons stated against the ban. Among them is to save, because if it is often used it will certainly be damaged or run out quickly. Another reason is concerns about damage because teachers cannot use the media. This is usually related to using technology-based media such as Infokus. Problems like this that cause the development of religious teachers in using the media are restricted.
Then another problem found in the use of this media is related to the ability of the teacher. Of the two PAI teachers at the school, they did not have the ability to use the media. Not able to determine the media that can be used to support the delivery of material. Not able to create media that matches the subject matter. And unable to utilize technologybased media, ranging from making slides, operating the media to utilizing the facilities in it.

Actually religious instructional media can be created from any object, depending on the creativity that the teacher has in accordance with the material. Media can be created on any subject matter by using any object, but the media can also use existing objects such as television, movies, pictures, tapes, and so on. As long as it can be matched with the subject matter of religion that will be delivered.

Another thing that is an obstacle in the use of religious instructional media when teaching is because of the many activities in school. These activities are activities such as assessing student learning outcomes, other student administration activities and other activities. Because of these conditions, the teacher did not have time to make instructional media.

\section{Availability of instructional media in schools}

The availability of instructional media in schools are still less varied, even then the instructional media in general are not for PAI learning, there are already electronic media such as recorder type, television, infocus. However, this amount is not sufficient compared to the benefits and uses for teachers and students. Whereas non-electronic media such as green landscape images, hero images, paintings and others are available but not maintained. Besides that, instructional media is in the form of musical instruments such as drums, flutes, and others. There are also 
media in the form of science learning tools such as human body parts, animals and others. Mathematics learning tools such as cube images, blocks and others.

\section{Efforts of utilizing instructional media}

School efforts to improve the quality of PAI teachers in carrying out their duties. Among other things, what is usually done to improve the ability of teachers is the teacher working group activities (KKG PAI). In this organizational activity various aspirations of participants, both complaints in teaching and other matters related to the learning process can be overcome. In each activity, instructors or presenters are always brought in according to the participants' needs. And the teachers are given the opportunity to discuss and exchange ideas directly with the speaker. It also includes matters relating to the use of instructional media. In addition, religious teachers who have the ability to share knowledge with others.

\section{CONCLUSION AND RECOMMENDATION}

The findings obtained in the implementation of this study are in accordance with the formulation of the problems planned from the beginning. The conclusions are as follows:

1. Constraints in using instructional media are:

a. Feeling there is nothing lacking in the execution of their duties, so there is no need for assistance with varied instructional media.

b. School leaders do not always provide opportunities for religious teachers to use or use media that has been collected for the sake of savings because they are afraid of being damaged.

c. Do not have the ability to use religious instructional media.

d. Many activities at school such as completing student administration, assessment, and so on.
2. Availability of instructional media

In general, the availability of instructional media in schools where this research is carried out is still inadequate. Although several types of instructional media besides PAI instructional media such as pictures, posters, props, and electronic media already exist.

3. Efforts made to use instructional media.

School efforts to improve the quality of PAI teachers in carrying out their duties. Among other things, what is usually done to improve the ability of teachers is the teacher working group activities (KKG PAI). On that occasion religious teachers who have the ability to be more able to share knowledge with others.

PAI teachers should start trying to change their teaching habits. Trying to manage the time as best as possible so that the time available every day can be used optimally. School leaders must provide opportunities for religious teachers to be able to utilize all available collections of instructional media. If the religious teacher has not been able to use the instructional media, then it is not too late to try to learn it. Various methods are widely available to be used in learning the use of instructional media.

\section{REFERENCES}

Almeida, J. M., Krueger, J., Eager, D. L., \& Vernon, M. K. (2001). Analysis of educational media server workloads. Proceedings of the 11th International Workshop on Network and Operating Systems Support for Digital Audio and Video, 21-30. ACM.

Bates, T., \& Poole, G. (2003). Effective teaching with technology in higher education: Foundations for success.

Bhatt, G. D. (2001). Knowledge management in organizations: Examining the interaction between technologies, techniques, and people. Journal of Knowledge Management, 5(1), 68-75. 
Blase, J., \& Blase, J. (2000). Effective instructional leadership: Teachers' perspectives on how principals promote teaching and learning in schools. Journal of Educational Administration, 38(2), 130-141.

Butt, M., \& Kausar, S. (2010). A Comparative Study of Using Differentiated Instructions of Public and Private School Teachers. Malaysian Journal of Distance Education, 12(1).

Chen, B., \& Bryer, T. (2012). Investigating instructional strategies for using social media in formal and informal learning. The International Review of Research in Open and Distributed Learning, 13(1), 87-104.

Church, A. P. (2008). The Instructional Role of the Library Media Specialist as Perceived by Elementary School Principals. School Library Media Research, 11.

Egan, K. (2005). An imaginative approach to teaching. San Francisco.

Falahudin, I. (2014). Pemanfaatan media dalam pembelajaran. Jurnal Lingkar Widyaiswara, 1(4), 104-117.

Hackathorn, J., Solomon, E. D., Blankmeyer, K. L., Tennial, R. E., \& Garczynski, A. M. (2011). Learning by Doing: An Empirical Study of Active Teaching Techniques. Journal of Effective Teaching, 11(2), 40-54.

Hess, K. K., Carlock, D., Jones, B., \& Walkup, J. R. (2009). What exactly do "fewer, clearer, and higher standards" really look like in the classroom? Using a cognitive rigor matrix to analyze curriculum, plan lessons, and implement assessments. Retrieved May, 15, 2014.

Iffah, N. (2018). Pengembangan alat permainan edukatif (APE) untuk meningkatkan keterampilan motorik dan inlegensi anak TK. Lecturer Repository.

Jung, I., Choi, S., Lim, C., \& Leem, J. (2002). Effects of different types of interaction on learning achievement, satisfaction and participation in web-based instruction. Innovations in Education and Teaching International, 39(2), 153-162.

Lässig, S. (2009). Textbooks and Beyond: Educational Media in Context (s) Simone Lässig. Journal of Educational Media, Memory, and Society, 1(1), 1-20.

Laurillard, D. (2013). Rethinking university teaching: A conversational framework for the effective use of learning technologies. Routledge.

Levin, E., Pieraccini, R., \& Eckert, W. (2000). A stochastic model of human-machine interaction for learning dialog strategies. IEEE Transactions on Speech and Audio Processing, 8(1), 11-23.

Mahnun, N. (2012). Media Pembelajaran (Kajian terhadap Langkah-langkah Pemilihan Media dan Implementasinya dalam Pembelajaran). ANIDA', 37(1), 27-34.

Marrocco, M. M. (2009). Understanding and promoting transformative learning: A guide for educators of adults. Canadian Journal of University Continuing Education, 35(2).

Mayer, R. E. (2003). The promise of multimedia learning: Using the same instructional design methods across different media. Learning and Instruction, 13(2), 125-139.

Moleong, L. J., \& Surjaman, T. (1991). Metodologi penelitian kualitatif. Penerbit PT Remaja Rosdakarya.

Muhson, A. (2010). Pengembangan media pembelajaran berbasis teknologi 
informasi. Jurnal Pendidikan Akuntansi Indonesia, 8(2).

Newby, T., Stepich, D., Lehman, J., \& Russell, J. (2000). Instructional technology for teaching and learning: Designing instruction, integrating computers, and using media. Educational Technology \& Society, 3(2), 106-107.

Nurseto, T. (2011). Membuat media pembelajaran yang menarik. Jurnal Ekonomi Dan Pendidikan, 8(1).

Reiser, R. A. (2001). A history of instructional design and technology: Part I: A history of instructional media. Educational Technology Research and Development, 49(1), 53.

Rideout, V. (2014). Learning at home: Families' educational media use in America. Joan Ganz Cooney Center at Sesame Workshop. ERIC.

Rodgers, D. L., \& Withrow-Thorton, B. J. (2005). The effect of instructional media on learner motivation. International Journal of Instructional Media, 32(4), 333.

Skylar, A. A., Higgins, K., Boone, R., Jones, P., Pierce, T., \& Gelfer, J. (2005). Distance education: An exploration of alternative methods and types of instructional media in teacher education. Journal of Special Education Technology, 20(3), 25-33.

Smaldino, S. E., Lowther, D. L., Russell, J. D., \& Mims, C. (2008). Instructional technology and media for learning.
Sun, P.-C., \& Cheng, H. K. (2007). The design of instructional multimedia in e-Learning: A Media Richness Theory-based approach. Computers \& Education, 49(3), 662-676.

Sun, R., Slusarz, P., \& Terry, C. (2005). The interaction of the explicit and the implicit in skill learning: A dualprocess approach. Psychological Review, 112(1), 159.

Suryani, T. (2009). Implementasi model Desain Sistem Instruksional Berorientasi Pencapaian Kompetensi (DSI-PK) pada proses pembelajaran Pendidikan Agama Islam (PAI) di SMA Muhammadiyah 2 Sidoarjo (PhD Thesis). IAIN Sunan Ampel Surabaya.

Taiwo, S. (2009). Teachers' Perception of the Role of Media in Classroom Teaching in Secondary Schools. Online Submission, 8(1).

Todd, R. W., Chaiyasuk, I., \& Tantisawetrat, N. (2008). A Functional Analysis of Teachers' Instructions. RELC Journal, 39(1), 25-50.

Williams, C. J., \& Jacobs, A. M. (2009). The impact of otitis media on cognitive and educational outcomes. Medical Journal of Australia, 191(S9), S69S72.

Wina, S. (2008). Strategi Pembelajaran Berorientasi Standar Proses pendidikan Jakarta. Kencana Prenada Media Group. 